\title{
Pelaksanaan Pengawasan Serta Penegakan Hukum Keimigrasian Dalam Pelanggaran Keimigrasian Overstay
}

\author{
Chrisna Erlangga Surbakti, Deozzy Anugerah Pratama, Ferdyan Asgar* \\ Program Studi Hukum Keimigrasian, Politeknik Keimigrasian \\ *Correspondence email: ferdyan.a76@gmail.com
}

\begin{abstract}
Abstrak. Negara Indonesia merupakan negara yang pusat wisata orang asing dari berbagai negara. Hal ini didukukan karena Indonesia memiliki kekayaan dan pesona alam yang memukau membuat Indonesia menjadi daya tarik untuk menjadi destinasi wisata. Melihat potensi tersebut pemerintah Indonesia mempermudah akses untuk masuk ke negara Indonesia. Namun pada kenyataannya, kebaikan pemerintah Indonesia disalahgunakan oleh orang asing tersebut. Banyak pelanggaran-pelanggaran keimigrasian yang mereka lakukan selama berada di Indonesia, seperti bertempat tinggal melebihi batas waktu yang telah ditentukan atau sering disebut Overstay. Dalam menangani kasus tersebut, pemerintah melakukan berbagai upaya dalam menangani permasalahan pelanggaran Keimigrasian. Pengawasan terhadap orang asing merupkan bentuk upaya oleh pemerintah dalam hal menangani kasus Overstay yang dilakukan orang asing di Indnesia. Dalam pelaksanaannya pemerintah juga melakukan penegakan hukum terhadap orang asing yang melakukan pelanggaran Overstay sehingga dapat mengurangi angka pelanggaran tersebut.
\end{abstract}

Kata kunci: Penegakan; Pengawasan; Overstay.

Abstract. Indonesia is a country that is a tourist center for foreigners from various countries. This is supported because Indonesia has a wealth and stunning natural charm that makes Indonesia an attraction to become a tourist destination. Seeing this potential, the Indonesian government facilitates access to enter the country of Indonesia. But in reality, the kindness of the Indonesian government was abused by these foreigners. Many of the immigration violations they committed while in Indonesia, such as staying beyond a predetermined time limit or often called Overstay. In handling these cases, the government made various efforts in dealing with the problem of immigration violations. Supervision of foreigners is a form of effort by the government in terms of handling Overstay cases carried out by foreigners in Indonesia. In its implementation, the government also enforces the law against foreigners who commit Overstay violations so as to reduce the number of violations.

Keywords: Enforcement; Overstay; Surveillance

\section{PENDAHULUAN}

Di masa modern yang serba digital ini, lalu lintas keluar dan masuk orang asing ke wilayah Indonesia semakin mengalami peningkatan. Hal tersebut didukung dengan letak geografis negara Indonesia yang sangat luas serta memiliki banyak sekali pulau. Di lain hal, Indonesia juga memiliki banyak sekali kekayaan alam baik flora maupun fauna yang secara tidak langsung menjadikannya sebuah daya tarik bagi wisatawan asing supaya datang berkunujung ke negara Indonesia. Negara Republik Indonesia mempunyai zona wilayah yang sangat luas, Indonesia berbatasan dengan banyak negara yang ada di asia tenggara, kebanyakan mayoritas negaranya adalah negara anggota ASEAN. Bali adalah salah satu contoh destinasi wisata Indonesia yang paling banyak diminati oleh wisatawan asing dari mancanegara karena memiliki panorama alam yang sangat indah.

Tetapi tidak semua Orang Asing bisa datang dan memasuki negara Republik Indonesia ini, hanya orang yang masuk dalam prinsip selective policy yang bisa memasuki negara Indonesia. Pada intinya orang asing yang diperkenankan memasuki negara Indonesia adalah orang yang bermanfaat bagi Indonesia, tidak membahayakan Indonesia, serta taat dan patuh terhadap peraturan perundang-undangan yang telah dibuat di
Indonesia. Oleh karena itu Imigrasi memiliki peran penting dalam menyeleksi orang asing yang ingin datang dan memasuki wilayah Indonesia.

Kementrian Hukum dan Hak Asasi Manusia dalam hal ini adalah Direktorat Jenderal Imigrasi memiliki peraturan untuk orang asing yang ingin memasuki negara Indonesia dan tinggal di wilayah Indonesia harus mempunyai izin tinggal. Ada beberapa macam izin tinggal di Indonesia antara lain, yaitu Izin tinggal kunjungan,Izin tinggal tetap,Izin tinggal terbatas,Izin tinggal diplomatik,dan Izin tinggal dinas. Orang asing yang sudah diizinkan masuk dan diperbolehkan berada di wilayah Indonesia, dan juga telah memperoleh izin tinggal sesuai dengan kepentingan dan tujuannya datang ke Indonesia. Penerapan kebijakan selektif yang Telah dilakukan oleh Pemerintah Indonesia melalui izin berkunjung, pengawasan,dan tindakan administrasi keimigrasian terhadap orang asing. Dalam hal ini Imigrasi mempunya peran dalam tatanan kenegaraan yang bisa di ketahui melalui penerapan lalu lintar orang, pemberian izin tinggal serta melakukan pengawasan orang asing di Indonesia.

Organisasi imigrasi adalah instansi pemerintah yang langsung bersinggungan dengan masalah keluar 
masuknya orang asing Indonesia, mulai sejak orang asing tersebut memasuki wilayah Indonesia, ketika berada di negara Indonesia serta juga melakukan kegiatan di Indonesia, maupun pengaturan orang asing yang akan keluar dari negara Indonesia, Imigrasi dituntut untuk lebih efektif dan efisien demi untuk menjamin dampak lalu lintas orang asing tersebut lebih banyak menguntungkan daripada dampak yang merugikan bagi kepentingan Indonesia. Pengaturan yang dimaksud ini merupakan pengaturan tentang keberadaan orang asing serta kegiatan yang mereka lakukian di wilayah Republik Indonesia. Untuk lebih mengetahui keberadaannya, izin tinggal yang digunakan oleh orang asing bisa dilakukan pengecekan apakah sudah sesuai dengan yang dikeluarkan dan kegiatannya yang mereka lakukan pada saat berada di wilayah negara Indonesia , apakah orang asing selama di wilayah Republik Indonesia melakukan kegiatan- kegiatan yang sesuai dengan izin tinggal yang diberikan. Dengan adanya pengaturan dan pengawasan yang dilakukan dapat diketahui keberadaan orang asing ketika sudah masuk dan berada di wilayah Republik Indonesia, sehingga terciptanya pengawasan orang asing yang efektif dan efisien. Keberadaan serta kegiatan orang asing Indonesia dapat diketahui dengan cara melakukan pengawasan orang asing yang dilaksanakan oleh bidang Pengawasan dan Penindakan Keimigrasian. Bidang tersebut melakukan pengawasan dengan cara melakukan pengawasan terhadap data-data maupun informasi orang asing yang berada di wilayah Republik Indonesia.

\section{METODE}

Penelitian ini menggunakan metode penelitian hukum normatif yang didukung oleh data-data yang terdapat di lapangan. Penelitian iniImerupakan penelitian di bidang hukum yang bersifat deskriptif, dengan pendekatan perundang-undangan dan juga pendekatan analisis. Jenis data yang dikumpulkan dan digunakan adalah bahan hukum primer dan bahan hukum sekunder. Teknik pengumpulan data yang digunakan adalah dengan melalui analisis Undang-Undang dan studi kepustakaan agar memperoleh dan melengkapi data-data yang diperlukan dalam penelitian ini

\section{HASIL DAN PEMBAHASAN}

Pelaksanaan pengawasan Keimigrasian Berdasarkan Undang-Undang Nomor 6 Tahun 2011 Tentang Keimigrasian

Keimigrasian menurut Undang-Undang No. 6 tahun 2011 Pasal 1 angka 1 adalah hal ihwal lalu lintas orang yang masuk atau keluar wilayah Indonesia serta pengawasannya dalam rangka menjaga tegaknya kedaulatan negara. Perlu diketahui bahwa Pengawasan keimigrasian ialah sebuah proses pengumpulan datadata, penganalisaan data-data dan juga menetukan bilamana suatu hal yang diawasi telah memenuhi standar yang sudah ditetapkan ataupun telah sesuai dengan
ketentuanI maupun peraturan-peraturan yang ada di Indonesia (Arif, 1997). Pada hakikatnya keimigrasian ialah pintu masuk atau garda terdepan dalam perlintasan masuk dan keluarnya Orang Asing maupun Warga Negara Indonesia serta pengawasan Keimigrasiannya yang berbasis pada keamanan dan intelijen Keimigrasian.

Selain pada urusan keamanan dan intelijen, keimigrasian pun melaksanakan beberapa fungsi pemerintahan dalam hal mengemban tugas pelayanan Keimigrasian, penegakkan hukum maupun keimigrasian sebagai fasilitator pembangunan kesejahteraan masyarakat Indonesia yang lebih dikenal sebagai catur fungsi Keimigrasian (Undang-Undang No. 6 tahun 2011 Pasal 1 angka 3). dalam rangka mewujudkan sistem keamanan nasional pada catur fungsi keimigrasian maka harus dilakukan berdasar pada konsep sekuritas maupun mengoptimalkan fungsi Intelijen Keimigrasian di dalamnya. Keimigrasian di Indonesia sendiri menganut sistem "Selective Policy" yang menyatakan bahwasannya hanya Orang Asing yang bermanfaat, tidak melanggar hukum di Indonesia, menaati peraturan peraturan Perundang-undangan yaitu Pancasila maupun Undang-Undang Dasar 1945,ini merupakan peraturan perundang-undangan yang berlaku di Indonesia, sesuai dengan tujuannya ke Indonesia, tidak menggangu keamanan dan juga ketertiban masyarakat yang dipersilakan masuk ke negara Indonesia (Pasal 75 dan Bagian Kesatu Penjelasan UndangUndang Nomor 6 Tahun 2011).

Menurut Peraturan Pemerintah nomor 31 tahun 2013 tentang peraturan pelaksanaan Undang Undang Nomor 6 Tahun 2011 Tentang Keimigrasian Pasal 172 angka 2, pengawasan keimigrasian yang dilakukan terhadap Orang Asing yang akan memasuki wilayah negara Indonesia dilakukan pada saat Orang Asing tersebut melakukan pengajuan visa pada perwakilan Republik Indonesia diluar negeri, selanjutnya ketika Orang Asing tersebut mulai datang ke wilayah Indonesia melalui TPI (Tempat Pemeriksaan Imigrasi) di bandara,Pelabuhan maupun Tempat Pemeriksaan Imigrasi lainnya, dan ketika orang Asing tersebut telah masuk, berada didalam Wilayah negara Indonesia dan sudah berkegiatan di wilayah Indeonesia. Pengawasan keimigrasian ini sendiri juga mencakup penegakannya terhadap Hukum Keimigrasian yang bersifat secara Administratif dan juga secara tindak pidana Keimigrasian. negara penerima Orang Asing memiliki tanggung jawab terhadap keberadaan Orang Asing di suatu negara tersebut, pada sisi yang lainnya, negara tersebut pun memiliki tanggung jawab untuk melindungi warga negaranya sendiri saat berada di wilayah negara lain, kewajiban negara tersebut meliputi kewajiban untuk menjamin kepentingan maupun keamanan warga negaranya sendiri maupun kewajibannya untuk melakukan pengawasan yang terukur untuk Orang Asing ketika berada di wilayahnya (Purbacaraka, 1987). 
Keberadaan Orang Asing di wilayah dapat ditinjau dalam 2 aspek yaitu yang petama mengenai keberadaannya di wilayah Indonesia maupun Izin tinggal apa yang digunakan dari Orang Asing itu dan yang kedua adalah Orang Asing tersebut selama berada di wilayah Indonesia melakukan kegiatan apa. jika melihat dari Pasal 38 Undang Undang Nomor 6 Tahun 2011 tentang Keimigrasian, pengawasan dilaksanakan kepada Orang Asing mengenai kegiatan maupun juga keberadaannya di negara Republik Indonesia,mengenai bentuk pengawasan pada bidang Keimigrasian tersebut yaitu mengumpulkan dan menganalisa mengenai data maupun informasi Orang Asing, kemudian menganalisa dan menentukan terhadap Orang Asing tersebut apakah Keberadaan dan Kegiatan Orang Asing Tersebut saat pertama kali masuk ke Indonesia maupun saat sudah masuk di wilayah Republik Indonesia sudah sesuai dengan peruntukannya, telah sesuai dengan Kaidah/Norma yang disepakati/berlaku untuk Orang Asing tersebut. Norma tersebut yaitu Hukum seperti peraturan perundangan yang masih berlaku terkait Izin tinggalnya,Izin kegitannya seperti Penanam Modal, mengikuti Pendidikan,Tenaga kerja, mengikuti Penelitian, penayatuan Keluarga, Repatriasi, dan lain lain. Selain Norma hukum, Orang Asing tersebut juga harus sesuai dengan Norma Sosial, Norma Agama, Norma Budaya, Norma Kesusilaan dan Norma lainnya yang berlaku di wilayah Republik Indonesia (Pasal 38 Undang Undang Nomor 6 Tahun 2011 tentang Keimigrasian).

Perlu diketahui juga pengawasan bagi Orang Asing sendiri merupakan tanggung jawab dari seorang Menteri Hukum dan Ham Republik Indonesia yang dimandatkan kepada Pejabat Imigrasi sebagai pelaksana pengawasan Keimigrasian, Pengawasan terhadap keluar dan masuknya Orang Asing di dalam negara Indonesia dilaksanakan oleh PEJIM (Pejabat Imigrasi) di TPI (Tempat Pemeriksaan Imigrasi) di Bandara, Pelabuhan, dan Tempat Pemeriksaan Imigrasi Lainnya. Jika dicurigai dan ditemukan suatu Pelanggaran maupun penyimpangan yang diperbuat oleh Orang Asing itu saat berada di TPI (Tempat Pemeriksaan Imigrasi), maka PEJIM (Pejabat Imigrasi) memiliki kewenangan untuk tidak memberi Izin Orang Asing itu untuk masuk ke negara Indonesia dan memberikan perintah kepada Orang Asing itu agar segera keluar dari wilayah Republik Indonesia menggunakan alat angkut yang digunakan oleh Orang Asing itu untuk memasuki wilayah Republik Indonesia dan untuk Penanggung jawab alat angkut tersebut agar dapat membawa Orang Asing itu keluar dari wilayah Indonesia dan kembali ke negara asalnya maupun ke tempat pemberangkatan terakhir Orang Asing tersebut dengan alat angkut yang lainnya dengan jaminan dari penanggung jawab alat angkut yang membawa Orang Asing itu ke wilayah Republik Indonesia (Arief, 1997). Selain Menteri Hukum dan Ham pada Undang-undang nomor 6 tahun
2011 tentang keimigrasian, disebutkan pada pasal 1 ayat (6), Direktorat Jenderal Imigrasi (Ditjen Imigrasi) ditetapkan sebagai direktorat yang melaksanakan tugas dan fungsi dari Kemenkumham (Kementerian Hukum dan Hak Asasi Manusia) Republik Indonesia dalam bidang Keimigrasian. Direktorat Jenderal Imigrasi memiliki peran penting sebagai garda terdepan yang menjaga pintu gerbang Negara Republik Indonesia yang memiliki kewajiban untuk melaksanakan seleksi bagi orang asing yang ingin dan akan memasuki wilayah negara Republik Indonesia. tugas dan kewajibannya yang melekat sebagai penunjang keamanan nasional dalam bidang Imigrasi untuk mengamankan, melindungi dan mempertahankan potensi-potensi Nasional dalam negara Republik indonesia serta mencegah dan menanggulangi setiap ancaman yang datan dari keberadaan Orang Asing dalam wilayah Hukum negara Indonesia.

Intelijen Keimigrasian untuk usaha dalam mengamankan dan melindungi kedaulatan wilayah negara Indonesia, maupun dalam melakukan pengawasan mengenai keberadaan maupun juga kegiatan dari Orang Asing merupakan tugas pokok dan fungsi dari keamanan negara pada catur fungsi Imigrasi. Dalam hal fungsi Intelijen Keimigrasian yang wewenangnya berada pada Direktorat Intelijen Keimigrasian tertuang pada Pasal 5 ayat (1), Undang-Undang Republik Indonesia Nomor 17 Tahun 2011 Tentang Intelijen Negara yang dimana dalam hal ini pengawasan berbasis intelijen dapat dilakukan oleh pihak Keimigrasian dan menjadikannya sebagai institusi atau lembaga negara garda terdepan yang menjaga pintu gerbang negara Indonesia. Kegiatan intelijen Keimigrasian sendiri merupakan kegiatan untuk melakukan pengumpulan, pengolahan, analisa data dan penyajian Informasi yang sedianya dipergunakan dalam memberikan keamanan dan mempertegas keamanan sejak dini maupun penganalisaan sebuah informasi secaraIstrategis. Dengan semakin canggihnya teknologi, dan juga semakin canggihnya modus pada para pealku kejahatan yang dilakukan perorangan maupun yang dilakukan oleh kelompok, petugas Imigrasi juga dituntut untuk lebih meningkatkan kompetensi dalam melacak segala macam kegiatan yang dapat berakibat kejahatan di dalam Keimigrasian. Penanggulangan terhadap ancaman kejahatan di dalam keimigrasian sendiri harus dengan baik di identifikasi oleh pihak Intelijen Keimigrasian sehingga dapat memprediksi dan memetakan dampak yang timbul dari ancaman ancaman kejahatan Keimigrasian kedepannya (Saleh, 2008).

Dalam rangka menjalankan fungsi Intelijen Keimigrasian, pada Undang-Undang nomor 6 tahun 2011 tentang Keimigrasian Pasal 74 ayat (2) menerangkan bahwasannya pejabat Imigrasi melaksanakan kegiatan penyelidikan dan Keamanan Imigrasi dan berwenang untuk dapat mengumpulkan Informasi dan data-data Intelijen dapat dilakanakan 
dalam dua cara diantaranya : 1 . Intelijen terbuka ialah dilakukannya pengumpulan informasi, rekaman data maupun catatan terhadap orang yang telah diberikanan Izin Keimigrasian, dan yang ke 2. yaitu Intelijen Tertutup yaitu pengumpulan informasi, rekaman data secara diam dan senyap tanpa diketahui dari target Intelijen tersebut. Pengawasan yang dilakukan oleh pihak keimigrasian berbasis Intelijen harus lebih ditingkatkan mengingat negara Indonesia merupakan negara transit dan memiliki intensitas perlintasan keluar dan masuk ke negara Republik Indonesia yang lumayan tinggi, dan tidak terlepas dari adanya pencari suaka (Asylum Seeker) dan juga Pengungsi (Refugee) dalam menjadikan negara Indonesia sebagai sebuah negara Transit menuju negara ke tiga penandatangan Konvensi Wina 1951, oleh karenanya peran pengawasan melaui Intelijen Keimigrasian sangat dibutuhkan dan berguna untuk keamanan keimigrasian bagi negara Indonesia dari ancaman dari pihak Asing ataupun Propaganda dari pihak Asing manapun.

\section{Bentuk Bentuk Pengawasan Orang Asing}

Orang Asing yang akan datang dan memasuki Indonesia harus sesuai dengan kebijakan "Selective policy" yang hingga saat ini masih berlaku untuk dapat memasuki wilayah Indonesia dan berada di negara Indonesia, maupun harus sesuai dengan maksud dan tujuan dari Izin tinggal Keimigrasian yang diberikan pada Orang Asing itu. Dengan demikian maka penting bagi pihak Keimigrasian untuk selalu memastikan Orang Asing yang akan memasuki wilayah negara Indonesia dan berada di sekitar wilayah Indonesia adalah Orang Asing yang bermanfaat, tidak melanggar hukum di Indonesia, menaati peraturan-peraturan Perundangundangan yang berlaku di Indonesia seperti Pancasila maupun Undang-Undang Dasar 1945, sesuai dengan tujuannya ke Indonesia, tidak menggangu keamanan serta ketertiban masyarakat yang boleh memasuki wilayah Indonesia, dan juga pengawasannya selama berada dan berkegiatan di wilayah negara Indonesia. Berdasarkan pada Peraturan Pemerintah No. 31 tahun 2013 tentang pelaksanaan Undang-Undang No. 6 tahun 2011 Pasal 174 ayat (1), pemeriksaan keimigrasian dilakukan dalam 2 cara yaitu :

1. Pengawasan administratif, dan

2. Pengawasan lapangan

Namun dalam pelaksaanaannya, dibutuhkan beberapa instansi terkait dalam pengawasan,dengan melakukan kegiatan penyelidikan, penggalangan dan pengamanan sehingga dapat disebut sebagai Pengawasan secara Koordinatif.

Pengawasan Administratif, pengawasan ini adalah pengawasan yang dilakukan menggunakan data Administratif pada setiap lembaga instansi terkait yang melaksanakan pengawasan, beberapa contoh data administratif yang dapat diperiksa maupun diteliti diantaranya:

1. Dokumen Perjalanan Republik Indonesia

2. Dokumen Perjalanan Negara Asing

3. Surat Sponsor

4. Surat Pernyataan

5. Surat Rekomendasi Instansi Terkait

6. Id Card

7. Register

8. Kartu Pengawasan

9. Formulir

10.Daftar Penumpang

11.Dan surat lainnya

Selain diperiksa dan di teliti, beberapa dokumen administratif tersebut dilakukan pengelolaan data keimigrasian maka apabila terjadi pelanggaran maupun penyimpangan dapat dilakukan penindakan sesuai dengan peraturan resmi yang berlaku di Indonesia.

Pengawasan Lapangan, pengawasan ini merupakan pengawasan dengan suatu taktik atau operasi lapangan yang dilakukan oleh pihak lembaga keimigrasian maupun dilakukan bersama-sama dengan beberapa lembaga ataupun instansi terkait yang dilakukan secara koordinatif, bentuk pengawasan ini yaitu berupa taktik menggali informasi, mendatangi tempat-tempat yang dicurigai dan patut diduga terdapat pelanggaran maupun kejahatan Keimigrasian yang diperbuat oleh Orang Asing baik terhadap keberadaannya di Indonesia maupun kegiatan apa yang diperbuat oleh Orang Asing tersebut ketika berada di Indonesia, apakah keberadaan Orang Asing itu telah sesuai dengan peruntukkannya atau tidak sesuai peruntukkannya, dan jika Orang Asing tersebut ditemukan bukti pelanggaran maupun kejahatan Keimigrasian maka dapat dilakukan penindakan sesuai dengan peraturan perundangan-undangan yang berlaku. Pengawasan terhadap Orang Asing sudah dapat dilaksanakan pada saat Orang Asing itu melakukan pengajuan Visa pada perwakilan negara Republik Indonesia di Luar Negeri, pada saat Orang Asing tersebut melakukan pemeriksaan Keimigrasian baik di Tempat Pemeriksaan Imigrasi bandara, pelabuhan, maupun Tempat Pemeriksaan Imigrasi lainnya, setelah Orang Asing tersebut sudah berada di Indonesia serta melakukan kegiatan di wilayah Republik Indonesia, dan sampai saat Orang Asing tersebut akan keluar dari wilayah Republik Indonesia.

Pengawasan Koordinatif, pengawasan ini adalah pengawasan yang dilakukan terhadap Orang Asing dilakukan bersama-sama dengan beberapa instansi terkait dalam melakukan pengawasan, penyelidikan, penggalangan,dan pengamanan. Kegiatan ini dilakukan dengan melakukan serangkaian kegiatan seperti interogasi, wawancara, pembuntutan, penyusupan, pengamatan, dan penggunaan Informan untuk mengawasi dan mendeteksi target yaitu Orang Asing, 
benda maupun bangunan. Pengawasan Koordinatif ini dilakukan juga dengan membentuk sebuah tim yang terdiri dari beberapa instansi terkait dengan pengawasan Orang Asing, tim ini sendiri dinamakan "TIMPORA" atau tim pengawasan Orang Asing, Timpora dalam pengawasan koordinatif dilakukan secara bertingkat, yaitu tingkat pusat, tingkat provinsi maupun tingkat Kabupaten atau Kota.

\section{Pengoptimalan Peran Tim Pengawasan Orang Asing (TIMPORA)}

Koordinasi antar Instansi pemerintah terkait sangat dibutuhkan guna mlakukan pengawasan kegiatan maupun keberadaan Orang Asing di suatu wilayah di Indonesia, maka dari itu pada akhirnya dibentuk Timpora atau tim pengawasan Orang Asing yang fungsinya sebagai wadah yang bertujuan untuk memberikan saran maupun pertimbangan-pertimbangan kepada lembaga atau instansi pemerintah terkait. Dalam hal pengawasan, operasi gabungan terhadap Orang Asing dapat dilakukan jika diperlukan, operasi ini dapat dilakukan dalam hal insidentil ataupun operasi secara khusus. Tim Pengawasan Orang Asing merupakan sebuah amanat undang-undang yang harus diimplementasikan oleh semua pihak terkait dikarenakan Timpora ini adalah sebuah kebijakan dari Pemerintah untuk melakukan pengawasan terhadap Orang Asing walaupun dengan keterbasan personel namun memang perlu melibatkan semua pihak. koordinasi dibutuhkan untuk menyatu padukan semua wewenang dari lembaga pemerintah seperti kementrian ataupun instansi terkait agar koordinasi tehadap pengawasan dapat berjalan dengan lancar dan meminimalisir hambatan.

Timpora yang dibentuk dari berbagai unsur-unsur lembaga pemerintahan menurut Undang-Undang Keimigrasian seperti :

1. Kementerian Hukum dan Hak Asasi Manusiai

2. Unsur Penegak Hukum

3. Unsur Pengamanan Negara

4. Instansi Pemerintah Daerah

5. Instansi Vertikal Lainnya

Hal tersebut dilakukan agar pengawasan terhadap Orang Asing dapat dilakukan dengan kordinasi yag baik antar lembaga, TIMPORA dibentuk di pusat maupun di daerah yang beranggotakan masing-masing perwakilan dari lembaga pemerintah atau instansi terkait lainnya baik di pemerintahan pusat maupun pemerintahan di daerah.

Untuk pembentukan TIMPORA di pusat dibentuk melalui Keputusan Menteri yang menjadi ketuanya ialah Menteri itu sendiri maupun Pejabat Imigrasi yang ditunjuk atau diamanatkan, kemudian Untuk pembentukan TIMPORA di tingkat provinsi dibentuk melalui Keputusan Kepala Kantor Wilayah Kementerian Hukum dan HAM yang diketuai oleh Kepala Divisi Imigrasi Kantor Wilayah Kementterian Hukum dan
HAM, kemudian untuk TIMPORA tingkat Kabupaten atau kota maupun di tingkat Kecamatan, dibentuk melalui Keputusan Kepala Kantor Imigrasi yang ketuanya Sendiri ialah Kepala Kantor Imigrasi.

Dalam hal pembentukan TIMPORA yang pada dasarnya ada dasar hukum yang sudah jelas agar setiap tindakan dari organisasi tersebut dapat berjalan dengan lancar dan baik dalam koordinasinya dan tentunya diharapkan setiap anggota harus dengan baik memahami perannya di ruang lingkup penugasannya, sehingga nantinya mereka dapat menjalankan peran dan fungsi mereka dalam mengawasi Orang Asing dengan baik dan lebih mudah Untuk dilakukan. TIMPORA saat dibentuk hingga saat ini masih hanya sebatas mengkoordinasikan tukar-menukar informasi dan memang dibutuhkan adanya suatu gebrakan baru yang membuat masingmasing anggota tim menjadi lebih aktif dalam menjalankan tugas,peran,dan fungsinya sesuai dengan ruang lingkup kerja mereka. dalam penugasannya untuk memberikan saran dan pertimbangan untuk lembaga atau instansi terkait, terdapat beberapa fungsi TIMPORA diantaranya:

1. Melakukan koordinasi guna mendapatkan pertukaran data dan juga informasi yang valid.

2. Melakukan pengumpulan informasi yang valid mengenai keberadaan Orang Asing tersebut secara bertingkat mulai dari tingkat desa, kabupaten atau kota, sampai ke Provinsi hingga ke tingkat pusat.

3. Melakukan analisa dan juga mengevaluasi semua data dan informasi tentang pelaksanaan pengawasan Orang Asing serta memetakan pengawasan terhadap Orang Asing itu sendiri.

4. Menyelesaikan masalah tentang keberadaan dan juga kegiatan Orang Asing di Indonesia.

5. Melaksanakan dan mengatur kerjasama dan juga hubungan baik dalam rangka pengawasan Orang Asing.

6. Menyusun strategi dan juga rencana dalam Operasi gabungan yang bersifat rahasia atau khusus maupun operasi yang bersifat insidentil dan operasi yang dilakukan secara mandiri oleh masin-masing instansi anggota TIMPORA.

7. Melakukan fungsi lainnya dalam pengawasan terhadap orang asing yang ditentukan oleh ketua TIMPORA itu sendiri.

Terkait dengan operasi rahasia atau khusus dapat dilakukan operasi gabungan oleh TIMPORA jika dirasa perlu, operasi tersebut merupakan operasi yang dilaksanakan dalam jangka waktu tertentu maupun kegiatan tertentu. Berbeda dengan operasi yang bersifat Insidentil yang dapat dilakukan operasi gabungan oleh TIMPORA sewaktu-waktu jika terdapat atau adanya laporan dari anggota TIMPORA maupun laporan langsung dari Madyarakat. Berikut adalah merupakan bentuk pelanggaran ataupun penyalahguaan yang di lakukan WNA di Indonesia: 
1. Overstay

2. Illegal stay

3. Tidak mampu memperlihatkan kepada petugas mengenai dokumen perjalanan serta lokasilkerja tidak sesuai

4. Melakukan Penyalahgunaan izin tinggal dimana izin tinggalIkunjungan digunakan oleh WNA untuk bekerja

\section{Penegakan Hukum Terhadap WNA yang terkena (Overstay)}

Di Indonesia cukup banyak orang asing datang ke wilayah Indonesia melalui Tempat Pemeriksaan Imigrasi. Ketika WNA sudah memasuki negara Indonesia, perlu dilaksanakan pengawasan keimigrasian harus dilakukan dalam hal untuk memastikan apa yang dilakukan oleh WNA sudah seusai dengan tujuan mereka mengajukan izin tinggalnya atau tidak. Jika dalam hal kegiatan orang asing tersebut tidak sesuai dengan tujuan mereka mengajukan izin tinggal di Indonesia, itu sudah termasuk sebagai penyalahgunaan Izin tinggal, atau jika waktu orang asing tersebut sudah lewat dari waktu yang di tentukan oleh izin tinggalnya bisa juga di sebut orang asing tersebut sudah Overstay. Overstay adalah suatu bentuk pelanggaran hukum dikeimigrasian dimana orang yang tinggal berada suatu tempat sudah lebih dari masa yang diizinkan atau dikehendaki.

Hukum Keimigrasian pada dasarnya merupakan salah satu bagian dari sistem hukum yang ada serta berlaku di wilayah Indonesia, Hukum Keimigrasian juga dikatakan sebuah subsistem dari Hukum administrasi Negara. Fungsi keimigrasian yaitu melakukan fungsi dari penyelenggaraan administasi negara, maka dapat di ketahui bersama hukum keimigrasian adalah produk hukum bagian dari bidang hukum administasi negara. Dalam hal ini, Penegakan Hukum yang dilaksanakan oleh petugas imigrasi terhadap WNA yang berbuat suatu pelanggaran Izin tinggal.

Hukum keimigrasian di buat selain untuk mengatur warga negara Indonesia, juga dapat mengatur WNA yang berada di walayah tersebu pada saat mereka berada di Indonesia. Dalam melakukan penegakan hukum keimigrasian, perlu dilakukannya tindakan pengawasan terhadap WNA.

Pengawasan yang dilakukan pemerintah dalam mengawasi WNA dilakukan dengan berbagai cara:

1. Melakukan pendataan nama-nama WNA yang tidak diperkenankan masuk ke Indonesia

2. Melakukan pengumpulan data tentag WNA yang masuk dan keluar Indonesia

3. Melakukan pemantauan WNA saat berada di Indonesia

Di dalam kantor Imigrasi, terdapat bidang yang mengawasi kegiatan orang asing yaitu seks Pengawasan dan Penindakan orang asing. Seksi tersebut dibentuk bertujuan untuk melakukan serangkaian kegiatan yang berkenaan dengan WNA mulai dari tempat tinggal WNA di Indonesia sampai dengan perilaku yang dilakukan WNA di Indonesia.

Orang Asing yang melakukan pelanggaran overstay akan diberikan sanksi membayar biaya beban, berdasarkan PP Nomor 28 Tahun 2019 serta dikenakan denda sejumlah Rp1.000.000. perharinya. Prosedur pembayaran biaya beban di kantor imigrasi pada saat orang asing melakukan perpanjangan izin tinggal yang terhubung dengan sistem :

1. Pejabat Imigrasi melakukan pemeriksaan persyaratan dan menemukan bahwa WNA tersebut telah overstay

2. Memasukkan data izin tinggal orang asing ke dalam sistem kemudian periksa jumlah overstay, pilih kode billing untuk menerbitkan kode billing sekaligus tanda terima pemohon. Apabila terjadi kesalahan pada jumlah overstay maka akan muncul tombol koreksi kemudian ubah jumlah overstay denga cara memasukkan tanggal masuk orang asing ke Indonesia kemudian meneruskannya ke kepala kantor imigrasi untuk mendapatkan persetujuan kemudian klik menu kakanim dan kembali cetak ke kode billing.

3. Orang asing atau penjamin pembayaran di Bank/ kantor pos.

Prosedur pembayaran biaya beban di kantor imigrasi pada saat orang asing melakukan perpanjangan izin tinggal tidak terhubung dengan sistem :

1. Petugas imigrasi membuka menu cetak, kode billling overstay,dan cetak kode billing overstay. Masukkan nomor permohonan dan klik tombol cari permohonan.

2. Membuat resume dan membubuhkan paraf untuk selanjutnya ditandatangani kakanim.

3. Mengisi data tanggal masuk dan masa berlaku izin tinggal. Klik tombol buat kode billing. Selanjutnya pindai tiket, tanda masuk pada halaman paspor dan resume. Klik tombol cetak untuk mencetak kode billing.

4. Orang Asing atau penjamin melakukan pembayaran di Bank/Pos persepsi.

Prosedur pembayaran biaya beban di kantor imigrasi pada saat orang asing melakukan perpanjangan izin tinggal yang terbukti overstay 60 hari :

1. Orang asing mengajukan ketidaksanggupan membayar biaya beban overstay lebih dari 60 hari.

2. Permohonan dibatalkan secara sistem dan pilih tombol wasdakim.

3. Kemudian dilanjutkan pada tahapan standar operating prosedur di bidang/ seksi inteldakim untuk mengirimkan data ke aplikasi nyidakim.

Deportasi bagi Orang Asing yang terkena overstay dilakukan Jika Orang Asing tersebut berada di Indonesia melebihi batas waktu yang ditentukan yaitu 60 hari, 
tetapi orang asing tersbut tidak bisa mebayar biaya beban, maka dilakukan deportasi. Jika Orang Asing itu Tidak mampu menunjukan izin tinggal dan juga dokumen perjalanan Nikah siri dengan WNI namun tidak memiliki izin sesuai dengan peruntukannya (ITAS Bekerja) dan jika Orang Asing itu Tidak bisa menunjukkan dokumen perjalan dan izin tinggal yang berlaku.

TIMPORA dapat menjalankan tugasnya dengan baik pasti memiliki beberapa Faktor, pengoptimalan pengawasan terhadap orang asing dapat berjalan dengan lancar dan baik apabila masing-masing pihak terkait dapat memahami tugas,peran dan fungsinya masingmasing,pembagian kerja yang jelas, menjalankan SOP yang ada dan menekan ego sektoral dapat menjadi faktor pendukung berhasilnya koordinasi kegiatan pengawasan yang dilakukan terhadap pengawsan Orang Asing oleh TIMPORA di Indonesia, kemudian dengan adanya payung hukum yang jelas, peraturan perundangundangan, kelembagaan ataupun instansi, ketatalaksanaan yang baik dan pemanfaatan Informasi, teknologi dan komunikasi tentunya juga menjadi faktor yang sangat berpengaruh terhadap berhasil atau tidaknya kegiatan pengawasan yang dilakukan terhadap Orang Asing di Indonesia.

\section{SIMPULAN}

Negara Indonesia merupakan negara yang pusat wisata orang asing dari berbagai negara. Hal ini didukukan karena Indonesia memiliki kekayaan dan pesona alam yang memukau membuat Indonesia menjadi daya tarik untuk menjadi destinasi wisata. Melihat potensi tersebut pemerintah Indonesia mempermudah akses untuk masuk ke negara Indonesia. Namun pada kenyataannya, kebaikan pemerintah Indonesia disalahgunakan oleh orang asing tersebut. Banyak pelanggaran-pelanggaran keimigrasian yang mereka lakukan selama berada di Indonesia, seperti bertempat tinggal melebihi batas waktu yang telah ditentukan atau sering disebut Overstay. Pengawasan keimigrasian yang dilakukan terhadap Orang Asing atau Warga Negara Asing yang akan memasuki wilayah Indonesia dilakukan pada saat Orang Asing tersebut mengajukan visa pada perwakilan Republik Indonesia diluar negeri, selanjutnya ketika Orang Asing tersebut akan masuk ke wilayah Indonesia melalui TPI (Tempat Pemeriksaan Imigrasi) di bandara,Pelabuhan maupun Tempat Pemeriksaan Imigrasi lainnya, dan saat orang Asing tersebut telah masuk, berada di Wilayah Indonesia dan sudah berkegiatan di wilayah Indeonesia. Pengawasan keimigrasian ini sendiri juga mencakup penegakannya terhadap Hukum Keimigrasian yang bersifat secara Administratif dan juga secara tindak pidana Keimigrasian. negara penerima Orang Asing memiliki tanggung jawab terhadap keberadaan Orang Asing di suatu negara tersebut, di sisi lain, negara tersebut juga memiliki tanggung jawab untuk melindungi warga negaranya sendiri saat berada di wilayah negara lain, kewajiban negara tersebut meliputi kewajiban untuk menjamin kepentingan maupun keamanan warga negaranya sendiri maupun kewajibannya untuk melakukan pengawasan yang terukur untuk Orang Asing ketika berada di wilayahnya. Keimigrasian pun melaksanakan beberapa fungsi pemerintahan dalam hal mengemban tugas pelayanan Keimigrasian, penegakkan hukum maupun keimigrasian sebagai fasilitator pembangunan kesejahteraan masyarakat Indonesia yang lebih dikenal sebagai catur fungsi Keimigrasian. dalam rangka mewujudkan sistem keamanan nasional pada catur fungsi keimigrasian maka harus dilakukan berdasar pada konsep sekuritas maupun mengoptimalkan fungsi Intelijen Keimigrasian di dalamnya. Keimigrasian di Indonesia sendiri menganut sistem "Selective Policy" yang menyatakan bahwasannya hanya Orang Asing yang bermanfaat, tidak melanggar hukum di Indonesia, menaati peraturan peraturan Perundang-undangan yaitu Pancasila maupun Undang-Undang Dasar 1945,ini merupakan peraturan perundang-undangan yang berlaku di Indonesia, sesuai dengan tujuannya ke Indonesia, tidak menggangu keamanan dan juga ketertiban masyarakat yang dipersilakan masuk ke negara Indonesia.

\section{DAFTAR PUSTAKA}

Arief, Mohammad. Keimigrasian di Indonesia Suatu Pengantar (Jakarta: Pusdiklat Departemen Kehakiman, 1997).

Arif, Moh., Komentar Undang-Undang Keimigrasian Beserta Peraturan pemerintah, Jakarta, Pusat pendidikan Dan Latihan Pegawai Departemen Kehakiman, 1997.

Purbacaraka, Purnadi. Penerapan Disiplin Hukum dan Filsafat Hukum bagi Pendidikan Hukum (Jakarta; Rajawali, 1987)

Saleh, John Sarodja. Sekuriti dan Intelijen Keimigrasian: Perspektif Lalu LintasAntar Negara, Jakarta: Direktorat Jenderal Imigrasi Departemen Hukum dan HAM RI; 2008

Undang Undang Nomor 6 Tahun 2011 tentang Keimigrasian

Undang-Undang Republik Indonesia Nomor 17 Tahun 2011 Tentang Intelijen Negara 